\title{
The Development of Performance Evaluation Model in the Academic Supervision School to Improve High School Quality
}

\author{
Lia Yuliana \\ Education Management \\ Yogyakarta State University \\ Yogyakarta, Indonesia \\ yulianauny@gmail.com
}

\author{
Eka Sapti Cahyaningrum \\ Early Childhood Education \\ Yogyakarta State University \\ Yogyakarta, Indonesia \\ eka_sapti@yahoo.co.id
}

\begin{abstract}
The purposes of this study were to: 1) find the steps in developing a model to evaluate the school superintendent's performance of academic supervision in improving the quality of high school in Yogyakarta, 2) obtain the feasibility model to evaluate the school superintendent's performance of academic supervision in improving the quality of high school in Yogyakarta, and 3) determine the effectiveness of the performance evaluation model of academic supervision in improving the quality of high school in Yogyakarta. This research uses Research and Development which consists of four stages: 1) the preliminary stage, 2) the planning stage of school superintendent performance evaluation model, 3) the pilot phase, evaluation and revision, and 4) the implementation stage. The subjects have done 3 stages: pre-trials involving 4 experts and practitioners, piloting high school scale applied by 6 supervisors, and implementation applied by 20 school supervisors in Yogyakarta, Bantul, Sleman, Gunung Kidul and Kulon Progo. The data used the Delphi technique through a questionnaire that was distributed to the experts, practitioners, and regulators, and used expert judgment and descriptive quantitative analysis techniques. The results showed: 1) the step-by-step model to evaluate the school superintendent's performance of academic supervision and apply research development procedurally, 2) the guidelines on the implementation model to evaluate school superintendent performance, the evaluation guide, the legibility instruments, the level of performance, and the level of performance were categorized as excellent, and 3) the level of school superintendent performance were also categorized as excellent.
\end{abstract}

Keywords-modeling, evaluation, performance, superintendent of schools, and the quality of the school.

\section{INTRODUCTION}

Acts No 20, 2003 about national education system defines education as conscious and planned effort where the students can develop their potency actively in order to have good teaching and learning atmosphere and have strength in spiritual, emotional, personality, and ability for themselves, community and nation. [1] adds education as someone's process that has dynamic and creative and involves time, place, and the condition of environment. While, Montessori in [1] states that education is needed in order to develop someone's independent, initiative, individuality, and self-direction, where he has responsibility to cooperate, care to his environment around, and unselfishness.

Another practitioner, Jackson in [2], Openjuru, and Mazur (2012) describes education as a process of give-and-take knowledge, skill, and attitude through some varieties of teaching and learning in order to prepare an individual to be a responsible people. Education can be also a vehicle in improving human fund and cultural preservation [3].

Education is a necessary asset to enhance the community social, economy, and culture, people awareness to their environmental condition, and have them good ability and ideology to accomplish their problems [2]. Based on those definitions above, it can be said that we have to be more aware how important education is, where it can be planned systematically in order to have optimal program and system in education. Learning activities as the sub-system of education activities may develop optimal atmosphere in teaching and learning process, where the students can actively develop their potency based on their aptitudes and interests.

Education in Indonesia is established through variety of education in line, level, and type. The education line as the students' mode develops their potency in an education process that based on the education objectives. While, there are 3 kinds of education line, which are formal, nonformal and informal education.

[2] define formal education as structured, certified, supported, and have clear written curriculum in education. Coombs et al. in [2] add that formal education is a structured education system from the very basic education to high education in university and academic learning program generally. While, nonformal education is everything about education outside the school system that does not have time and space parameters [4]. In addition, informal education is established by an organization that has not classroom activity and unstructured education system[2]. 
The improvement of education quality in Indonesia is more real due to the implementation of national education system. When educational institution reaches the education national standards, the education quality also improves. The policies about educational quality improvement has been formulated and implemented in order to have high education quality. One of the school quality component as education sub-system is the existences of strategic superintendents' role. Educational quality issue in Indonesia cannot be separated by supervision management that implemented by academic superintendent and school principal [5].

Supervision of education system cannot be separated in school quality improvement effort. According to Robbins [6], supervision is a monitoring process where all of the organization's activities are carried out as planned and it can be repaired if it is found any irregularities that would interfere the organization's goal. [6] adds that supervision as management function that is used to evaluate the organization performance in order to establish a progress that related to the guidance and its objective. In addition, academic supervision as a series of activities that help teachers develop their ability in managing and facilitating learning activities and achieving goals effectively and efficiently.

The main issue problem faced by school in improving education quality is that the school superintendent's role and performance has not optimal yet. School superintendent has strategic role as a quality control component that functioned in supervision field for implementing the school supervision function. School superintendent can assess the school performance, the superintendent and teacher performance in implementing the school programs.

The phenomena indicates that school quality is not appropriate yet and the school superintendent role in academic supervision field is still lack. Therefore, it is expected to have a research about evaluation model development of school superintendent performance in academic supervision field in improving high school quality in Special Region of Yogyakarta.

School superintendent should have optimal, professional, and fast respond roles to school dynamic in order to be able to accomplish the duties effectively and efficiently. School superintendent must aware of the objective's achievement that has been determined by each education institution. The ability of school superintendent influences the school quality improvement. This study focuses on evaluation model of school superintendent performance in academic supervision field in improving high school quality Special Region of Yogyakarta.

Based on the background of the study, it can be formulated that:

1. What are the steps of evaluation model development of school superintendent performance in academic supervision field in improving high school quality Special Region of Yogyakarta?
2. What are the eligible evaluation model development of school superintendent performance in academic supervision field in improving high school quality Special Region of Yogyakarta?

3. How is school superintendent performance level in academic supervision field in improving high school quality?

Based on the problem formulation above, the aims of the study are to:

1. Find the steps in developing a model to evaluate the performance of the school superintendent field of academic supervision in improving the quality of high school in Yogyakarta

2. Obtain the feasibility model to evaluate the performance of the school superintendent field of academic supervision in improving the quality of high school in Yogyakarta, and

3. Determine the effectiveness of the performance evaluation model field school superintendent academic supervision in improving the quality of high school in Yogyakarta.

\section{LITERATURE REVIEW}

\section{A. Evaluation Model Concept}

Theoretically, evaluation is a systematic effort to collect, arrange and process the data that consists of information, where value, meaning, achievement, and result can be used in a purpose. It is as a mean for recognizing something may go and its criteria should be determined before evaluation is conducted [7]. Stufflebeam in [7] adds that evaluation as a cycle that not only used for clarifying and measuring the objectivity, but also it is used to adapt the learning material and method. TenBrink in [13] classify 3 process of evaluation model:

1) clear steps in evaluation process,

2) whole evaluation problems that can be used,

3) Understandable and usable.

Evaluation model developed by Tyler is relevant with this research. Tyler model can be used for assessing school superintendent performance in academic supervision field as a program to improve school performance.

[7] wrote 7 steps according to Tyler evaluation model:

1) determine clear objectives,

2) classify the objectives,

3) define the objectives,

4) determine the situations where the objectives' achievement could be shown,

5) develop the technique of measurement,

6) collect the data, and 
7) compare the data with the previous objectives. Therefore, a good test is a test that has validity, realibility, practicality, economic, and objectivity [8].

\section{B. School Superintendent Performance in Academic Supervision Field}

Supervision is the first level of organization management [9]. Falender in [9] adds that supervision is a real professional activity where education and training as knowledge development is processed by collaborative interpersonal. [10] draws supervision as an organizational duty that promotes professional development, teaching and learning practice for the students' achievement in ecological, cooperative and formative activities.

In addition, according to [11] education supervision involves necessary duty in education system that is changing and improving education status in purpose. The academic supervision's essence is not only for assessing the teacher's performance in managing the learning process, but also for helping teacher to develop his professional capability. It is expected to have improvement in academic quality that conducted by teachers [5].

Instructional supervision affects teacher behavior in facilitating the students' learning and achieving organization's objectives [5]. School performance will be improved by the enhancement of superintendent performance both academic and managerial field. [12] add that academic supervision provides supervision's framework and progressive, systematic, and academic input for the students and also supports academic staff to supervise many students at a time.

Superintendent performance in academic supervision field affects the academic quality improvement. Anderson in [6] states that performance is a work result or outcomes and its contribution to organization. Nawawi in [6] adds performance as someone's achievement in a particular expertise, in performing his duties effectively and efficiently. While, [6] defines performance as someone's ability to achieve his job objectives, that is not only about managing, but also leading and applying all of his capabilities.

In order to achieve good performance, a teacher should try to develop all of his competencies to establish good school environment. Marwansyah in [6] explains some factors that affect performance: 1) employees' psychological factors capability which is the potential ability (IQ) and education; and 2) motivational factor which is the employee's attitude on work.

In accordance with the Ministerial Regulation Number 12 of 2007 on the standard of competence supervisor, the performance of supervisor can be measured based on personality, social, supervisory managerial, supervisory academic, evaluation of education, and research and development competence. Sudjana in [6] adds that the performance of school supervisor can be seen from supervision, performance, profession development and the impact of school quality development.

Academic supervision is a supervision function that related to the teacher's professional ability and development within the improvement of learning quality. Sergiovanni in Ambarita (2014) explains academic supervision objectives as:

1) academic supervision organized to help teachers in developing professional understanding to their academic ability and teaching skills by using certain techniques,

2) academic supervision held to monitor teaching and learning acitivity in schools, and

3) academic supervision organized to encourage teachers in implementing ability to perform teaching duty have a commitment and responsibility in the classroom.

[1] add that the main academic supervision purposes is to help the teachers recognize educational objectives, guide teaching and learning experiences, use learning resources, methods of teaching, the students' learning needs, assess the students' learning progress, teaching morale, collaborate with the community, and establish educational school atmosphere.

[6] Regular supervision by using supervision strategies such as checking the students' notebooks, monitoring classroom activities, checking teachers' lesson plan and record, has significant correlation with the teachers' performance and improvement and also the students' academic achievement in Secondary Schools. Supervision as educational program development is also necessary for developed country. The education system in Usman's research place showed that the students' achievement and the students' way of teaching were still low. The education system needs professional expertise approach in order to improve educational industry in his country.

[6] Stated that in recognizing supervision's competence and performance both conceptually and contextually can implemented by supervisory duties. The scope of educational supervision includes managerial oversight and academic supervision. Academic supervision improves the quality of the teacher's teaching and learning process in order to have good result. In addition, the monitoring dimension activities are 1) the preparation, 2) the implementation, 3) the evaluation of supervision program, and 4) the guidance for professional training of principals and/or teachers. Those dimensions associated with the improvement of school competency. It is also believed that in having good performance, it will lead to the service quality of improvement, learning improvement, and the quality of school management.

\section{RESEARCH METHOD}

This study uses Research and Development method, which is a process used develop and validate educational product (Borg and Gall). In research based development, it purposes to improve educational quality. It is used for obtaining evaluation 
model of school superintendent performance in improving high school quality Special Region of Yogyakarta. This study consisted of 4 stages:

1. The preliminary stage which is the stage of research and information gathering regarding to the performance of supervisory high school Special Region of Yogyakarta,

2. The planning stage of school superintendent performance evaluation model as the development of the product shape initial

3. The pilot stage, evaluation and revision through the implementation of the pre-trials and high school scale trials, and

4. The implementation stage or field operational test to find maps of the school superintendent performance.

The data collection technique used delphi technique where researcher collected the data through questionnaire addressed to experts, practitioners, and supervisor.

This study was held in 5 places Special Region of Yogyakarta, which were Sleman, Bantul, Kulon Progo, Gunung Kidul, and Yogyakarta city, by using proportional random sampling. The data analysis used descriptive study by using statistical and computer program. Quantitative data analysis is used for analyzing instrument validity and evaluation of school superintendents' performance, with a criteria below.

TABLE I. THE CONVERSION OF QUANTITATIVE DATA TO QUALITATIVE DATA

\begin{tabular}{|l|l|}
\hline Score & Classification \\
\hline$>4.2$ & Excellent \\
\hline$>3.5-4.2$ & Very Good \\
\hline$>2.5-3.4$ & Good \\
\hline$>1.5-2.4$ & Less \\
\hline$\leq 1.4$ & Very Less \\
\hline
\end{tabular}

\section{RESULTS AND DISCUSSION}

Based on the discussion result between researchers and experts in this study, it was decided theoretical agreements. Evaluation of School Superintendents' Performance (ESSP) developed in this study is a model used to evaluate the performance of the school superintendent in the field of academic supervision to improve the quality of high school in Yogyakarta. Research and Development (R \& D) activities were through the pre-surveys, theoretical study including relevant study research, needs analysis, empiric tryout test, and field practice.

ESSP concept generated through such a long process of research team discussion, experts' discussions, seminar instruments, and the appropriateness test in the field. Before this instrument was tested, all the items have been validated by experts and practitioners of management education. The theoretical, empirical, and practical study and intensive discussions with the research team and the various parties through field trials showed that the instrument of ESSP was good or feasible to be used to assess the performance of the school superintendent both Special Region of Yogyakarta as an area of research and on a national scale as a generalization result.

The results showed that:

1. The procedure of developing models of evaluation of the school superintendents' performance in academic supervision field in improving the quality of high school in Yogyakarta has been applied research development procedurally;

2. The guidelines on the implementation model to evaluate the school superintendent's performance in academic supervision field in improving the quality of High school in Yogyakarta declared eligible by the experts where the feasibility of the instrument was evidenced by a mean score of 4.30 or categorized as excellent.

While, for the evaluation guidance was also rated excellent with a mean score of 4.60. As for legibility instruments valued by 6 school supervisors, it obtained mean score of 3.90 or categorized as very good. The evaluation guidance was 4.00 and also in very good category. The level of performance that was assessed by 6 school superintendents had 1.94 or excellent category. While, the level of performance assessed by 10 high school teachers was 1.92 or excellent category;and

3. The level of school superintendents' performance as an effort to improve the quality of high school rated by 20 school supervisors showed the average score of 1.88 or excellent category. While, the level of performance assessed by 20 high school teachers was 1.94 or excellent category.

1) Instrument Readability of School Superintendent's Performance

The validity implementation of ESSP instrument legibility done by 10 people. Those are the evaluation experts of education, education management experts (4 experts) and school supervisor (6 people). Based on the results of expert assessment, the mean score indicated that the instrument as a whole was good or feasible with a mean score of 4.30 or categorized as excellent (between the values of > $4.2-5.0$ ). The validator also asked to provide comments and input relating to the legibility of ESSP instrument in improving the quality of high school. Recommendations or feedback given by the validator concerned with the instrument legibility of indicators, systematics, terms, concepts, and regarded to the school superintendents' performance.

Based on the results of the feasibility assessment instruments of ESSP experts and school superintendents, the general conclusion is that the instrument is already good. The 
results of expert assessment showed excellent results, while the assessment of school supervisors categorized as very good. This difference can be understood in theoretical perception regarding to the experts' perceptions and the school faculty empirically. But it still can be concluded that ESSP instrument was feasible to be implemented in schools in order to assess the performance of the school superintendent.

In addition, based on the results of expert assessment of the performance evaluation guide of school supervisors, it showed that the model guide of ESSP was good or feasible with a mean score of 4.60 or excellent category (between the value of $>4.2$ - 5.0.) The assessment result of the school superintendents' performance evaluation showed that the model guide of ESSP was also good or feasible with a mean score of 4.00 or very good category (between the value of $>3.5$ - 4.2).

2) Performance Level of School Superintendent Special Region of Yogyakarta in the Main Test

Based on the results of a major trial against 6 high school supervisors and 10 high school teachers on the performance level of high school superintendent Special Region of Yogyakarta, it referred to the evaluation standard of the high school superintendents' performance by using ESSP instruments. It is included in the category of very high, namely 96.5. This includes all components of ESSP.

\section{3) Trial Implementation or Operational Courses}

Based on the evaluation of school supervisors and teachers about the performance level of high school superintendents Special Region of Yogyakarta on the implementation of the test field, it is referring to evaluation standards of high school superintendents' performance by using ESSP instruments. It is also included in very high category, namely 95.5. This includes all components of ESSP.

It can be concluded that the research model development can generate ESSP model either through a preliminary study, needs analysis, planning stage, implementation stage, revision and evaluation, or implementation.

Based on ESSP model of the needs assessment in the school, both supervisors and teachers assessed that the model is necessary used to monitor the performance of the school superintendents, especially in the field of academic supervision.

After assessing the needs analysis, it is very important to determine or formulate the ESSP instrument development. Based on the expert assessment after going through various revisions of the discussion, it can be resulted that ESSP model and instruments were rated as excellent by four experts. The evaluation guide categorized as excellent with a score of 4.30 and for ESSP instrument was 4.60. This showed that the ESSP model was excellent to be applied and the instruments was very feasible to use.
Likewise with the assessment of 6 high school superintendents against ESSP model and instruments, it indicated that both of them were good. Both models and instruments were appropriate to be applied to assess the school superintendents' performance Special Region of Yogyakarta in improving the quality of schools.

Based on the evaluation, the result obtained 3.90 and 4.00 for ESSP instrument. It showed that ESSP model was also appropriate to be applied and the instrument was eligible to be used. Beside the assessment through questionnaire, it was also held the observations and interviews with school supervisors to support a finding that the instrument and the model was needed, especially for school supervisor department Special Region of Yogyakarta. In addition, it is expected to make this model can be used throughout Indonesia or national scope.

In the trial main test stage applied by 6 high school superintendents and 10 high school teachers Special Region of Yogyakarta, it could be concluded that the school superintendents' performance was excellent with a mean score of 96.5. It was not only based on the self-assessment of school superintendents, but also based on the assessment of teachers to the school superintendents.

The findings was also supported by observations and interviews with teachers and school superintendents where it indicated that high school superintendent's performance was excellent. The performance should be maintained and even improved so that it can support school improvement.

Likewise, based on the field operational test stage applied to 20 high school superintendents and 20 high school teachers Special Region of Yogyakarta, it could be concluded that the performance was excellent, where the mean score was of 95.5. It was not only based on the self-assessment school superintendents, but also based on the assessment of teachers to the school superintendents. This showed that the assessment was done with a high objectivity level and the data was not biased.

The findings in the study was also supported by observations and interviews with teachers and school superintendents. It indicated that the school superintendents' performance was excellent. The school superintendent's performance should be maintained and even improved so that it can support school improvement. Based on the results of the evaluation of the school superintendents' performance at the implementation stage, it can be arranged in the following form. 
TABLE II. EVALUATION RESULT OF SCHOOL SUPERINTENDENTS' PERFORMANCE

\begin{tabular}{|l|l|l|l|l|l|l|l|}
\hline \multirow{2}{*}{ No. } & \multirow{2}{*}{$\begin{array}{l}\text { Assess- } \\
\text { ment } \\
\text { Aspect }\end{array}$} & Mean & \multicolumn{3}{|l|}{ Classification } & \multicolumn{2}{l|}{} \\
\cline { 3 - 7 } & Score & VL & L & G & VG & E \\
\hline 1 & $\begin{array}{l}\text { Academic } \\
\text { Super- } \\
\text { vision } \\
\text { Field }\end{array}$ & 95.50 & & & & & $V$ \\
\hline
\end{tabular}

VL = Very Less; L = Less; G = Good; VG = Very Good; E $=$ Excellent

Evaluation result of school superintendents' performance: Excellent

\section{CONCLUSION}

Based on the research results and discussion of the study, it can be concluded that:

1) the step-by-step model to evaluate the performance of the school superintendent field of academic supervision in improving the quality of high school in Yogyakarta to apply research development procedurally

2) guidelines on the implementation model to evaluate the performance of the school superintendent field of academic supervision improve the quality of high school in Yogyakarta declared eligible by experts in which the feasibility of the instrument is evidenced by a mean score of 4.30 or very good, while for the evaluation guide is also rated very good with a mean score of 4.60. The legibility instruments valued by 6 supervisors schools obtain either category mean score of 3.90 , while the evaluation guide 4:00 also good category, while the level of performance that is assessed by the school superintendent 6 of 1.94 or excellent category. While the level of performance that is assessed by 10 high school teachers of 1.92 or excellent category

3) the level of performance of the school superintendent as an effort to improve high school assessed by 20 school supervisors showed the average score of 1.88 or excellent category. While the level of performance that is assessed by 20 high school teachers amounted to 1.94 criteria very well. While the performance of the school superintendent on average based on assessment of the school superintendent and high school teachers amounted to 95.50 or excellent categories.

\section{ACKNOWLEDGMENT}

Researchers would like to thank the educational department that this study can be utilized in assessing the high school superintendents' performance in improving the quality of schools and all of the school superintendents so that they can improve their performance continuously, especially in the field of academic supervision.

\section{REFERENCES}

[1] Engel, Liba H. 2013. The Democratic School and the Pedagogy of Janusz Korczak: A Model of Early Twentieth Century Reform in Modern Israel. International Journal of Progressive Education. Volume 9 Number 1. (pp. 119-132)

[2] Engel, Liba H. 2013. The Democratic School and the Pedagogy of Janusz Korczak: A Model of Early Twentieth Century Reform in Modern Israel. International Journal of Progressive Education. Volume 9 Number 1. (pp. 119-132)

[3] Sahlberg, Pasi. 2007. Education policies for raising student learning: the Finnish approach. Journal of Education Policy. Vol. 22, No. 2, March 2007, pp. 147-171

[4] Jumani, NB \& Rahman, Fazal-ur. 2011. Potential of non formal basic education in promoting women education in pakistan. International Journal of Instruction. Vol.4, No.1. pp 17-32

[5] Ambarita, Biner. Et al. 2014. Development of Academic Supervision Model which Based on Educational Management. International Journal of Sciences: Basic and Applied Research (IJSBAR). Volume 18, No 1. pp 304-314

[6] Ansar. 2015. Measuring the Performance of School Superintendent. Journal of Education and Practice. Vol.6, No.2. pp 103-108

[7] Kuo, Lung-Hsing. Et al. 2012. An Evaluation Model of Integrating Emerging Technology into Formal Curriculum. International Journal Of Education And Information Technologies. Issue 3, Volume 6. Pp 250259

[8] Arikunto, Suharsimi. (2010). Dasar-dasar evaluasi pendidikan. Jakarta: Bumi Aksara.

[9] Potmesilova. Et al. 2013. Supervision as a Prevention and Support to Teachers in Inclusive Education. Electronic Journal for Inclusive Education. Volume 2, Number 11. Pp 1-12

[10] Coimbra, Maria de Nazaré Castro Trigo. 2013. Supervision and Evaluation: Teachers' Perspectives. International Journal of Humanities and Social Science. Vol. 3, No. 5. Pp 65-71

[11] Jahanian, Ramezan \& Ebrahimi, Mitra. 2013. Principles for Educational Supervision and Guidance. Journal of Sociological Research. Vol. 4, No.2. $380-390$

[12] Nordentoft, et al. 2012. Collective academic supervision: a model for participation and learning in higher education. Springer Science Business Media

[13] Usman, Yunusa Dangara. 2015. The Impact of Instructional Supervision on Academic Performance of Secondary School Students in Nasarawa State, Nigeria. Journal of Education and Practice. Vol.6, No.10. pp 160167

[14] Arikunto, Suharsimi \& Cepi Safruddin AJ. (2004). Evaluasi program pendidikan, panduan teoritis praktis bagi praktisi pendidikan. Jakarta: Bumi Aksara.

[15] Borg, W.R. \& Gall, M.D. (1989). Educational research: an introduction. NewYork \& London: Longman. 
[16] Burden, P.R \& Byrd, D.M. (1999). Method for effective teaching. Boston: Allyn and Bacon.

[17] Departemen Pendidikan Nasional. (2001). Manajemen Peningkatan Mutu Berbasis Sekolah. Jakarta: Ditjen Dikdasmen Depdiknas.

[18] Goetsch, Davis D L, Davis, Stanley B. (2006). Quality Management; Instroduction Total Quality Management for Production, Processing, and Service. Fift Edition: Pearson, Prentice Hall.

[19] Permendiknas Nomor 12 Tahun 2007 tentang Standar Pengawas Sekolah/Madrasah.

[20] Sudjana, Nana. (2005). Penelitian hasil proses belajar mengajar. Bandung: Remaja Rosdakarya.

[21] Sekretariat Negara, Undang-undang No. 20 Tahun 2003 tentang Sistem Pendidikan Nasional. Jakarta: Sekretariat Negara.

[22] Widoyoko, S. (2007). Pengembangan model evaluasi pembelajaran IPS di SMP. Yogyakarta: Disertasi Program Pasca Sarjana Program Studi Penelitian dan Evaluasi Pendidikan Universitas Negeri Yogyakarta 